\title{
Li Jingrong
}

\section{The Scribal Hands \\ of the Er nian lü ling Manuscript Unearthed from Zhangjiashan Han Tomb No. 247}

Abstract: Contrary to received texts, early Chinese manuscripts written on bamboo strips have typical physical features, of which handwriting is the significant character. This paper studies handwriting of the Er nian lï ling manuscript unearthed in the Zhangjiashan Han tomb No. 247. According to analysis on the monophony of the repeating characters in the manuscript, it concludes that the manuscript was most likely written by three scribes. One scribe who mastered professional writing skills and was responsible for writing more than half of the bamboo strips is the main one among the three. As the Er nian lü ling manuscript was required for the tomb owner's funeral, it was written by three scribes together within a short time resulting in a number of transcribe errors in the text.

Key words: Handwriting, scribe, legal manuscript, early China, Zhangjiashan

Since 1970 s, manuscripts found in tombs have provided valuable information for research on legal history and law development in early China. In contrast to texts handed down to us, a manuscript has physical features. Therefore, we should study the important features including layout, shape, dimension, binding, punctuation marks, writing and scribal hands, which will help us better understanding the production and purpose of a manuscript as well as its text.

This paper is a case study about the scribal hands for a manuscript named Er nian lü ling (The Statutes and Ordinances of the Second Year, ENLL), which was excavated from the Zhangjiashan Han tomb no. 247 (in Jiangling district, Hubei) sealed around 186 BCE. Its text contains twenty-seven cate-

(C) Li Jingrong, Changsha, Hunan University

Note of the Author: This article is an expanded and updated version of a Chinese paper, Zhangjiashan ersiqi hao Han mu Er nian lü ling shushou shuti shixi 張家山247號漢墓 《二年律令》書手、書體試析, published in Hunan University Journal (Social Science) 2016 (4): 38-43. 
gories of statutes and one sort of ordinance of early Han, which is highly valuable for research on Han laws. ${ }^{1}$

A couple of scholars have shown interest in scribal hands and writing of the ENLL manuscript. Chen Yaojun and Yan Pin assumed that the ENLL text was written by more than one scribe including the owner of the tomb, while they did not give any reasons for this conclusion. The article was published two years after the excavation of Zhangjiashan tomb no. 247, but the ENLL text was not published at that time. ${ }^{2}$ Tomiya Itaru states that multiple scribes took part in producing the ENLL manuscript by citing an example, in which there are different morphological forms for a part of a recurrent character. ${ }^{3}$ His view will be discussed later in the article. Zhang Zhongwei shares the same statement, but he does not analyse handwriting of the ENLL manuscript. ${ }^{4}$

The writing on the ENLL bamboo slips is in the form of clerical script (li shu 隸書). As the ENLL manuscript is a legal one with statutes and ordinances, there are fixed legal terms found frequently in the text and several grammatical particles common to ancient Chinese texts. The morphology of these repeated characters is an ideal criterion for distinguishing different hands. Three distinct handwritings can be identified in this manuscript, which are designated $\mathrm{A}, \mathrm{B}$ and $\mathrm{C}$ in this paper. The following table summarises the contrast displayed by frequently recorded characters written by the different scribes:

\begin{tabular}{|c|c|c|c|}
\hline Characters & Scribe A & Scribe B & Scribe C \\
\hline \multicolumn{4}{|l|}{ 城 } \\
\hline & ENLL 48 & ENLL 55 & ENLL174 \\
\hline \multicolumn{4}{|l|}{ 旦 } \\
\hline & ENLL 48 & ENLL55 & ENLL174 \\
\hline
\end{tabular}

${ }^{1}$ The annotated transcription and the photographs of all the bamboo strips of the ENLL manuscript were first published in 2001, see Zhangjiashan ersiqi hao Han mu zhujian zhengli xiaozu 2001. For a detailed examination of the ENLL manuscript as well as an English translation of its text, see BARBIERI-LOW and YATES 2015.

${ }^{2}$ CHEN YAOJUN and YAN BIN 1985: 1126.

${ }^{3}$ TOMIYA 2010: 308.

${ }^{4}$ ZHANG ZHONGWEI 2012: 21. 


\begin{tabular}{|c|c|c|c|}
\hline 春 & ENLL 48 & ENLL55 & \\
\hline 及 & ENLL 1 & ENLL 182 & ENLL 176 \\
\hline 若 & $\begin{array}{l}{ }_{\text {ENLL } 18} \\
\text { thes }\end{array}$ & $\begin{array}{l}\frac{82}{35} \\
\text { ENLL } 57\end{array}$ & $\sum_{\text {ENLL }} 176$ \\
\hline 罪 & ENLL 15 & ENLL 60 & ENLL 176 \\
\hline 為 & ENLL 18 & ENLL 55 & ENLL 176 \\
\hline 人 & & ENLL 57 & ENLL 176 \\
\hline 册 & & & $\begin{array}{l}38 \\
\text { ENLL } 176\end{array}$ \\
\hline 而 & ENLL 65 & ENLL 71 & $\begin{array}{l}801 \\
\text { ENLL } 174\end{array}$ \\
\hline 子 & ENLL 38 & ENLL 68 & $\begin{array}{l}\text { ENLL } 174 \\
\text { ENt }\end{array}$ \\
\hline 不 & ENLL 1 & ENLL 55 & ENLL 176 \\
\hline 妻 & $\begin{array}{l}\text { है: } \\
\text { ENLL } 38\end{array}$ & ENLL 68 & 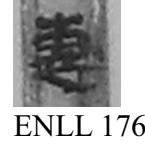 \\
\hline
\end{tabular}


The quality of the scribes' writing varies significantly: the characters written by scribe A are relatively elaborate and neat. The last right-falling stroke ( $n a$ 捺) of the characters is long in proportion to the whole character and its curve shows the "silkworm head and swallow tail" (can tou yan wei 䖯頭燕尾). The angle between the left-falling stroke (pie 粉) and the rightfalling stroke is bigger than that of characters written by scribe B and C. Additionally, the thickness of strokes is constant and the angles and curves run smoothly. The connects between curves goes flexibly and the characters are horizontally aligned.

Compared to the writings by A, scribe B wrote in a hasty and casual way. His characters are narrower and longer. The right side of his characters slants upwards, and they look less controlled and balanced. In addition, the structure of some characters such as (chong 春) and (wei 為) written by scribe A manifestly differs from that of the characters 汼 (chong 春) and (wei 為) completed by scribe B.

Scribe $\mathrm{C}$ wrote characters in a mostly square shape. There is a strong contrast among strokes, such as the last right-falling stroke ( $n a$ 捺) of the characters (zhi 之), 3 ( $j i$ 及), and (ren 人) is much thicker than other strokes, which indicates using more pressure during the writing of this stroke. Although scribe B usually wrote thick right-falling strokes, such as F. (ren 人) in ENLL 57; while compared to the one finished by scribe C, the whole character is longer and more dynamic, and the angle between the left-falling (pie 撇) and the right-falling stroke of the character is not as large as that of scribe $\mathrm{C}$.

In addition to the morphology of characters, the whole arrangement of the writing on bamboo slips differs from each other. For instance, from ENLL 48 to 59: ENLL 48-50 and 54 were written by scribe A, while ENLL 51-53 and 55-59 were finished by scribe B. It shows that the spacing between characters and size of his characters are almost the same. In summary, the writing on ENLL 48-50 is arranged neatly and orderly. Compared to the writing by scribe A, the characters of B are longer and the size of the characters varies significantly. All the writings on ENLL $51-53$ and 55-59 by scribe B slants upward so that it is more dynamic.

Special attention should be given to scribe A, who probably received professional training to have an elaborate and polished hand. He was also able to 
switch between two or three forms to write the same character. ${ }^{5}$ For example, the upper left components of 閐 on ENLL 76, 篮 on the upper part of ENLL 153, and $\frac{1}{2}$ on ENLL 74 (dao 盗) differ from each other. He also used the old form of the character 4 (zhi 之) on ENLL 86, which has four strokes. Despite the variations in terms of structure and form, these characters were most likely written by scribe A regarding to the running of the strokes and the structure of the components. Furthermore, such characters are found between other characters that can undeniably be attributed to scribe A.

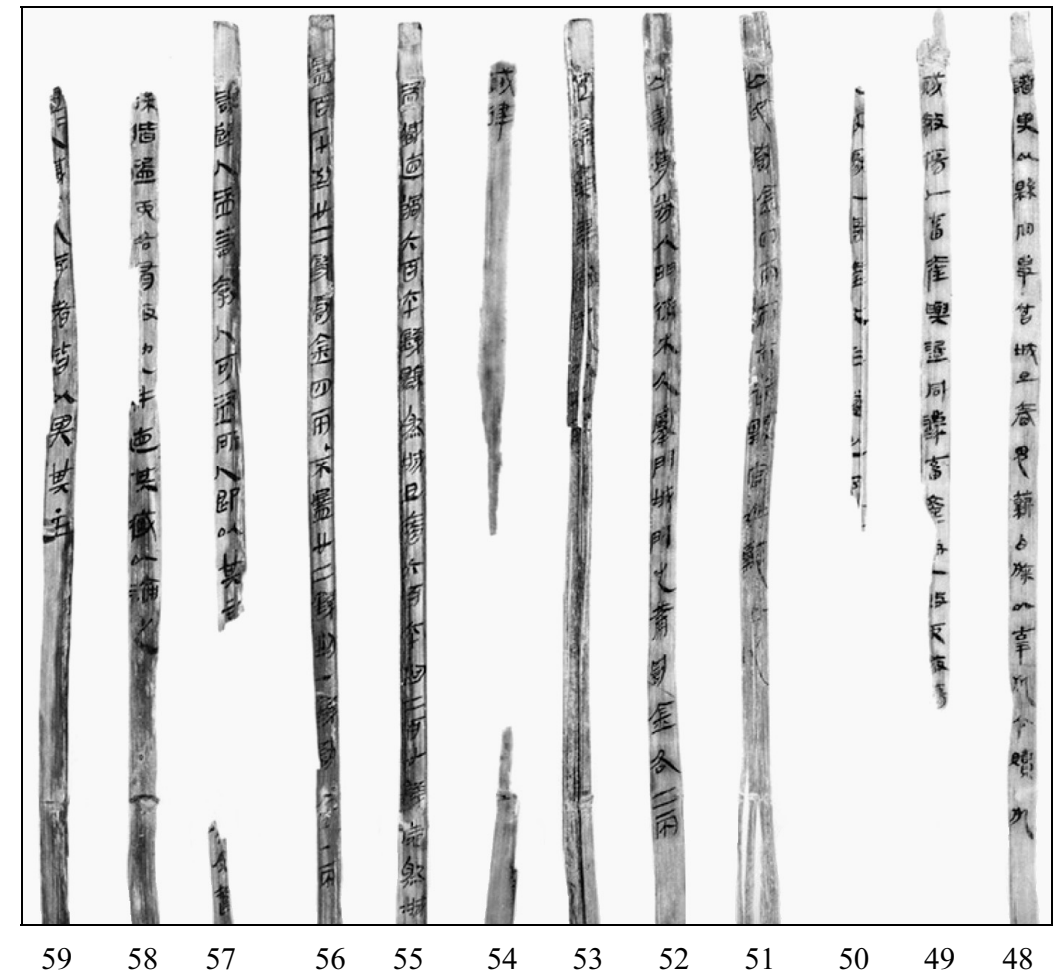

Fig. ENLL $48-59$

\footnotetext{
${ }^{5}$ The articles in Statutes on Scribes (Shi lü 史律) in the ENLL manuscript explicitly regulate the writing training and examination received by scribes. According to the statutes, scribes should command eight different styles of script (ba ti 八體). It seems that the eight styles may correspond to those mentioned by Xu Shen 許慎 in his epilogue to Shuowen 說文. However, what exactly the eight different styles of script were is not clear. Of these eight different styles mentioned by Xu Shen, some are defined by the writing materials; while others are defined by their morphological structure and shape; see XU Shen 1963: 315.
} 
Take ENLL 74 for example, Tomiya argued that ENLL 74 was written by two scribes indicating that the two records of the character dao 盜, 传 on the upper part and on the middle part have different upper left components. ${ }^{6}$ Besides this character, there are also other characters found twice or even three times on ENLL 174: $B$ (chu 出) (upper part), 4 (middle part), and 18 (bottom part); (zhi 致) and 数 (bottom part), $5=$ ( $f u$ 符) and (bottom part); (bottom part). In comparison, these characters are very similar; it is clear that one scribe must write them. The recurrent characters ( $j i$ 及), ( $l i$ 吏), 经 (jin 金), d ENLL 174 were apparently written by scribe A. In addition, the style and arrangement of the writing on the whole bamboo strip prove that this strip was written scribe A.

The variations between forms or structures of characters cannot be a single criterion to decide the scribe. The following table shows the different forms of some characters written by scribe A:

\begin{tabular}{|c|c|c|c|c|c|}
\hline Characters & \multicolumn{5}{|c|}{ Different forms of the same character by scribe $A$} \\
\hline \multirow[t]{2}{*}{ 之 } & & & 4 & & 2 \\
\hline & ENLL 1 & ENLL 15 & ENLL86 & ENLL 180 & ENLL262 \\
\hline \multicolumn{6}{|l|}{ 吏 } \\
\hline & ENLL 2 & ENLL 6 & ENLL 19 & ENLL 20 & ENLL 210 \\
\hline \multicolumn{6}{|l|}{ 法 } \\
\hline & ENLL 20 & ENLL49 & \multicolumn{3}{|l|}{ ENLL 75} \\
\hline \multicolumn{6}{|l|}{ 予 } \\
\hline & ENLL216 & ENLL 217 & ENLL 2 & & \\
\hline
\end{tabular}

\footnotetext{
${ }^{6}$ TOMIYA 2010: 308.
} 


\begin{tabular}{|c|c|c|c|c|c|}
\hline 足 & ENLL 140 & $\frac{z}{\text { ENLL } 24}$ & \multicolumn{3}{|c|}{ ENLL 255} \\
\hline 過 & both middl & part of EN & L 273 bott & om part of & LL 273 \\
\hline \multicolumn{6}{|c|}{ ENLL 312 lower part of ENLL 314 bottom part of ENLL 314} \\
\hline 盜 & ENLL 20 & ENLL49 & ENLL 66 & ENLL 74 & ENLL 74 \\
\hline
\end{tabular}

It seems that these characters were different and not written by an individual scribe. The style of the writing and the alignment of the characters support that scribe A wrote them. Take ( $l i$ 吏) on ENLL 20 for example, the lower parts of the characters were in a different form, but the upper parts were written in a very similar way. The style of the writing and morphological form of the other characters on ENLL 2 show that they were written by scribe A. For instance, the frequently

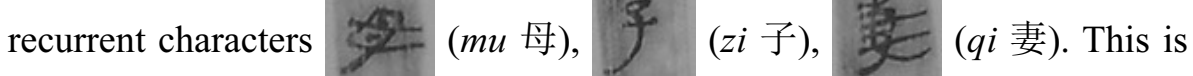
the same case as with strip ENLL 20, such as the characters $5 x$,

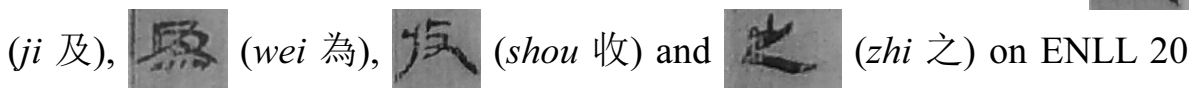
were completed in the typical form of scribe A.

Scribe A did not switch between the forms of a character for semantic reasons, even different forms of a character can be found in the same phrase, such as 鼓 乙 ( xu zhi 許之, allowing to do it) on ENLL 115 and 生. on ENLL 343. Another example is: 墇 in a gang) on ENLL 65, 粪 on the upper part of ENLL 153, on the middle part of ENLL 153, and on ENLL 155. 
Scribe A switched between the forms of a character frequently when he wrote the same character several times onto the same strip, as we can see in the examples of guo 過 on ENLL 273, yuan 遠 on ENLL 314, and dao 盜 on ENLL 74 and 153. Scribe A might have done so for aesthetic reasons to avoid monotony during writing. It could be the case as well that scribe A switched the form and structure of a character at whim and these variations were made habitually without thorough consideration.

Since three scribes participated in writing this manuscript, it is important to find out the exact scribe assigned to write the specific ENLL text. ENLL 48-54 discussed above belong to the Statutes on Banditry (Zei lï 賊律), thus it is evident that both scribe A and B wrote the text belonging to a category of statutes. In summary, scribe A wrote ENLL 1-50 and 54 of the Statutes on Banditry, ENLL 54 was the last strip of this statute and its title was written there; while scribe B only wrote ENLL 51-53.

Is this the only category of statute that multiple scribes took turns to write? To answer this question, the whole manuscript will be examined in detail. The writing of ENLL 61-81 belonging to Statutes on Theft will be analysed firstly in the following table.

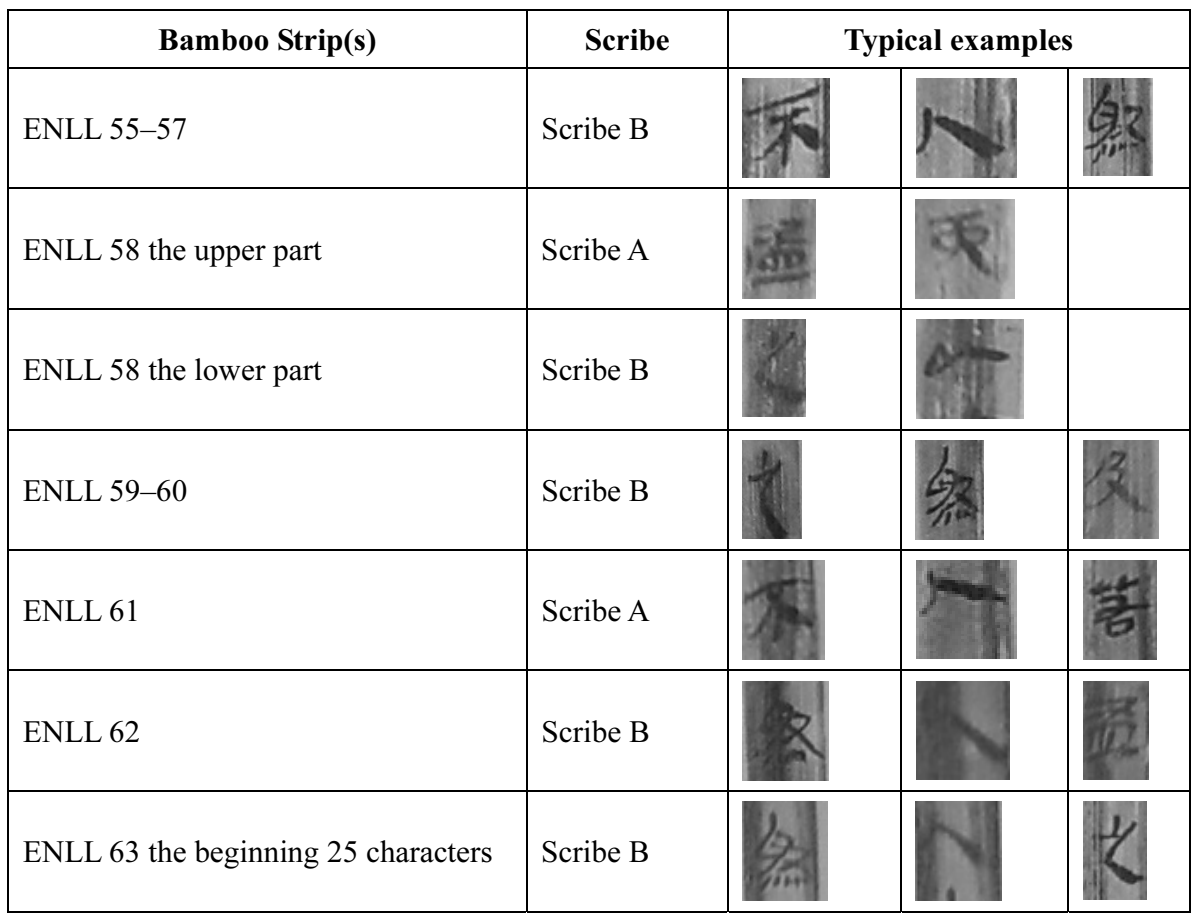




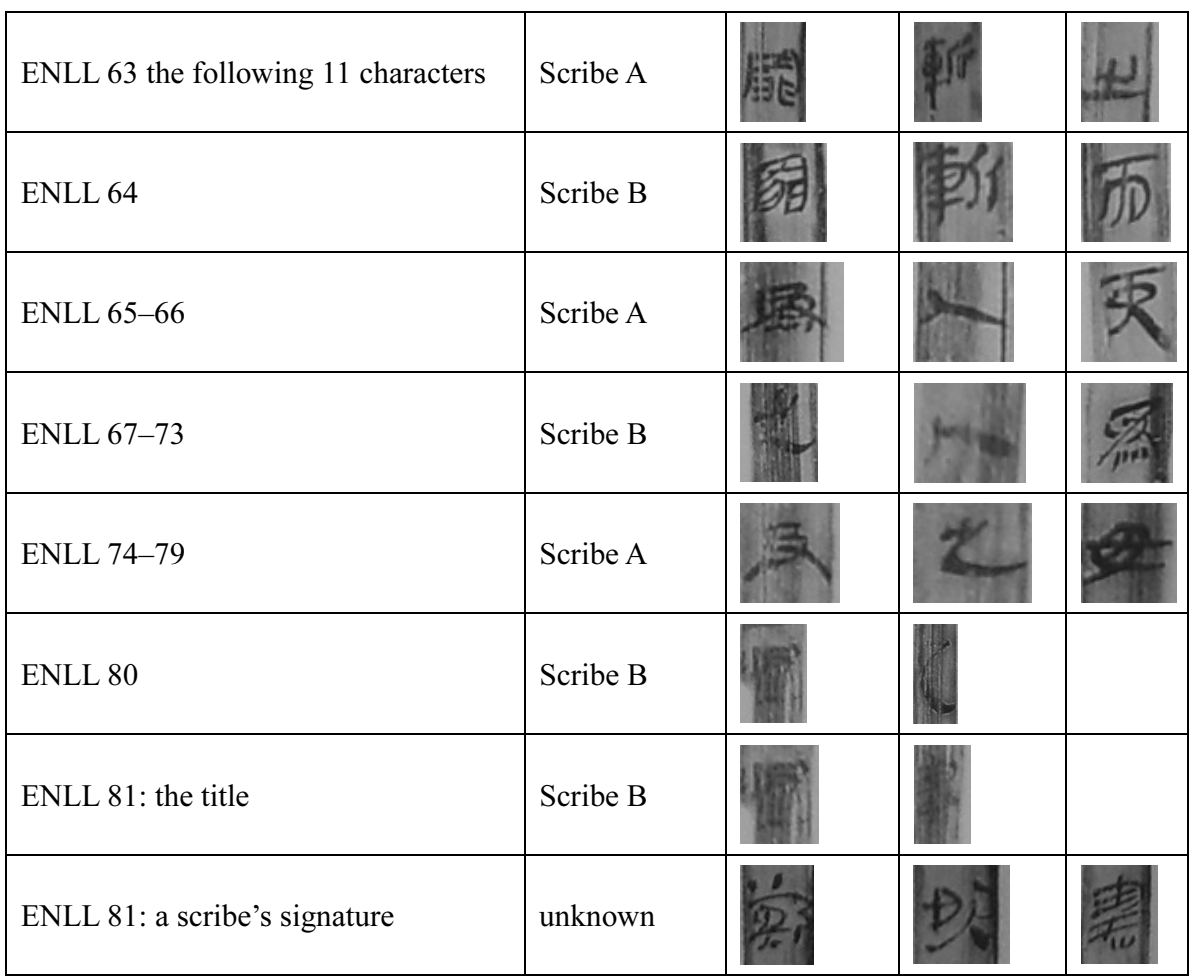

The above table shows that both scribe A and B took part in writing this statute. ENLL 58 and 63 were written by both of them. Special attention was given to ENLL 81, the last bamboo strip belonging to Statutes on Theft. It is found that the title "Statutes on Theft" (Dao lü 盗律) is on the top, while a scribe's name is written above the bottom binding string: "written by Zheng Kan?" (鄭㰠書). ${ }^{7}$ It is obvious that these three characters were written more hastily and sloppily than the ordinary "clerical script". It cannot be determined who wrote this statute, as the handwriting of the signature significantly differs from that of both scribes. Similar to the way that the appearance of modern signatures varies from ordinary writing, it may be normal for

\footnotetext{
${ }^{7}$ In Yates' opinion, "Zheng” written on ENLL 81 is "the name of a copyist either surnamed Zheng 鄭 or deriving from the city of Zheng plus a given name written with a graph with a 'woman 女' radical which is otherwise unknown." He concludes that the text of the ENLL manuscript was not copied by a female copyist whose name is "Zheng X;" instead, it suggests that this slip with her name on it had been used and recycled. Afterwards, the real scribe of the text did not erase the name from the slip. He did not give the detailed reason for this statement; see YATES 2014: 209-210.
} 
a scribe to use a special style for his signature rather than the one that he had learnt from the scribal school. ${ }^{8}$ However, it remains an enigma why only the one scribe's name can be found here, since this statute was written by both scribe A and B. It is the only 'signature' of a scribe that can be found in the whole manuscript. Regarding to the fact that the bottom part of the bamboo slips with the titles "Statutes on Issuing Food Rations to Post Stations" (Zhuan shi lü 傳食律) and “Statutes on Registration" (Fu lü 傅律) are lost, it is still theoretically possible that a signature was written on one of them or even both.

Besides the preceding two statutes of the manuscript, Statutes on Banditry and Statutes on Theft, there are other instances of multiple scribes participating in writing a category of statutes as well. The following examples compare the characters of different hands within one category of statutes:

Statutes on the Generalities (Ju lü 具律): ENLL 82-125

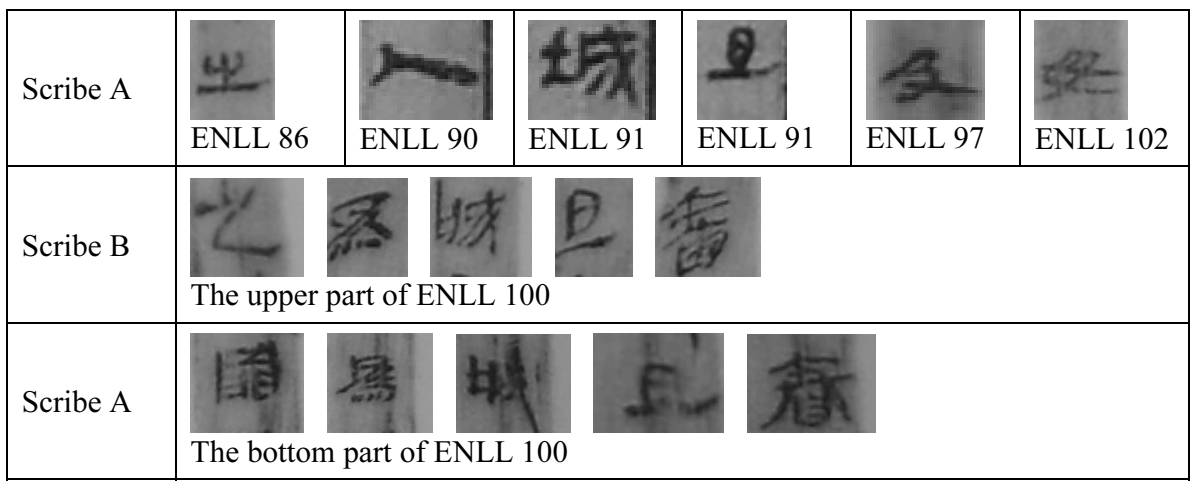

This statute was mainly written by scribe A, except for the upper part of ENLL 100 completed by scribe B.

\footnotetext{
${ }^{8}$ According to a Qin statute, only sons of scribes had the chance to study in scribal schools (xue shi 學室). QLSBZ 191: Ling: Shi wu cong shi guan fu. Fei shi zi yi, wu gan xue xue shi, fan ling zhe you zui. Nei shi za 令: 史冊從事官府。非史子殹, 冊敢學學室, 犯令者 有罪。內史雜, “According to the Ordinances . . . clerks must not be made to work in government storehouses. If (persons) are not sons of clerks, they must not venture to study in the study-room. Those who transgress this Ordinance will have committed a crime. (Statutes concerning) the Ministry of Finance; miscellaneous" (HuLSEwÉ 1985: A101). It should be noted that Hulsewé translated shi 史 as clerks rather than scribes. Giele discusses the signatures of "scribes" in the administrative manuscripts in early imperial China; see GIELE 2005: $353-387$.
} 
Statutes on Absconding (Wang lü 亡律): ENLL 157-173

\begin{tabular}{|c|c|c|c|c|c|}
\hline \multirow[t]{2}{*}{ Scribe A } & Sed & & & & $\frac{3}{7}$ \\
\hline & ENLL 160 & ENLL 163 & ENLL 166 & ENLL 168 & ENLL 170 \\
\hline \multirow[t]{2}{*}{ Scribe B } & & & & & \\
\hline & ENLL 164 & ENLL 172 & ENLL 164 & ENLL 172 & ENLL 172 \\
\hline
\end{tabular}

Most slips of this statute were written by scribe A, except for ENLL 164 and 172 written by scribe B.

Statutes on Enslavement and Confiscation (Shou lü 收律): ENLL 174-181

\begin{tabular}{|c|c|c|c|c|c|c|}
\hline Scribe & $\begin{array}{l}\text { zyll } \\
\text { ENLL } 178\end{array}$ & ENLL 178 & $\sum_{\text {ENLL } 179}$ & ENLL 180 & ENLL 180 & 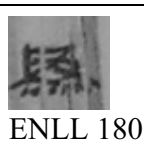 \\
\hline Scrib & ENLL 175 & ENLL 175 & ENLL 176 & ENLL 175 & & $\begin{array}{l}\text { ENLL } 176 \\
\text { EN. }\end{array}$ \\
\hline
\end{tabular}

ENLL 177-181 of this statue were written by scribe A, while ENLL 174176 were done by scribe $\mathrm{C}$.

Miscellaneous Statutes (Za lü 雜律): ENLL 182-196

\begin{tabular}{|c|c|c|c|c|c|c|}
\hline Scribe A & $\begin{array}{l}\mathrm{get} \\
\text { ENLL } 184\end{array}$ & $\begin{array}{l}\text { Ay } \\
\text { ENLL } 184\end{array}$ & ENLL 188 & ENLL 188 & $\begin{array}{l}\text { ENLL } 190 \\
\text { EST: }\end{array}$ & 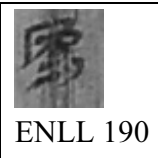 \\
\hline Scribe B & The beginni & ee cha & cters of ENL & L 193 & & \\
\hline Scribe A & The followi & $\mathrm{g}$ character & of ENLL 193 & & & \\
\hline Scribe B & ENLL 182 & ENLL 183 & ENLL 183 & $\begin{array}{l}\text { ENLL } 191 \\
\text { EN }\end{array}$ & ENLL 192 & ENLL 195 \\
\hline
\end{tabular}


ENLL 184-190 of this statute were written by scribe A, while ENLL 182183, 191-192 and 194-196 were completed by scribe B. In this statute, they both took part in writing one strip ENLL 193: Scribe B wrote the first three characters, while scribe A wrote the following characters.

Statutes on Appointment of Officials (Zhi li lü 置吏律): ENLL 210-224

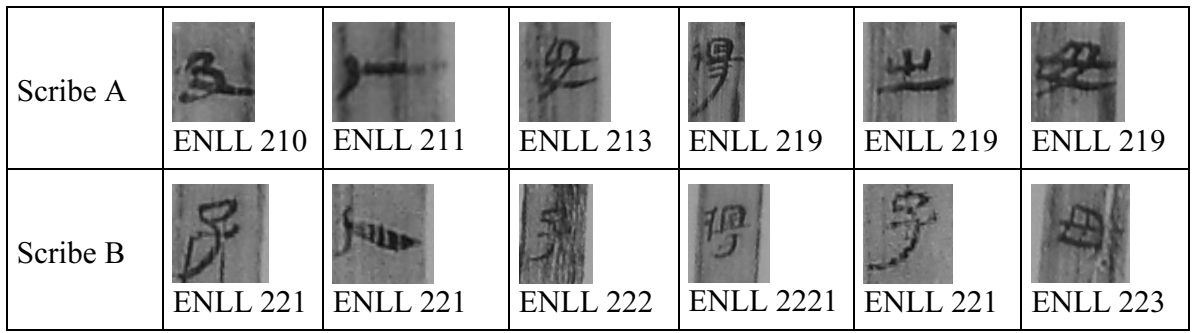

ENLL 221-224 were written by scribe $C$ and all the other slips of this statute were finished by scribe A.

Statutes on Household Registration (Hu lü 戶律): ENLL 305-346

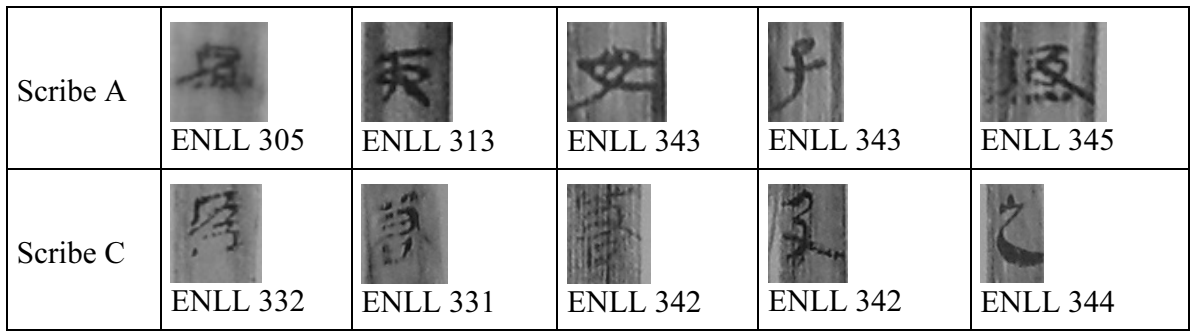

ENLL 331-332, 342 and 344 were written by scribe C, and all the other slips of this statute were done by scribe A.

All the statutes mentioned above were written by two scribes. Except for the bamboo slips relating to Statutes on Meritorious Rank (Jue lü 爵律) done by scribe $\mathrm{B}$, the other remaining statutes and one ordinance were probably all written by scribe A. ${ }^{9}$

\footnotetext{
${ }^{9}$ It should be mentioned that for certain slips it is impossible to exactly determine, by whom the bamboo slips were written, either because the ink had heavily faded and the writing cannot be distinguished anymore, or because the slips were only fragments at the time of excavation.
} 
Statutes on Meritorious Rank (Jue lü 爵律): ENLL 392-39

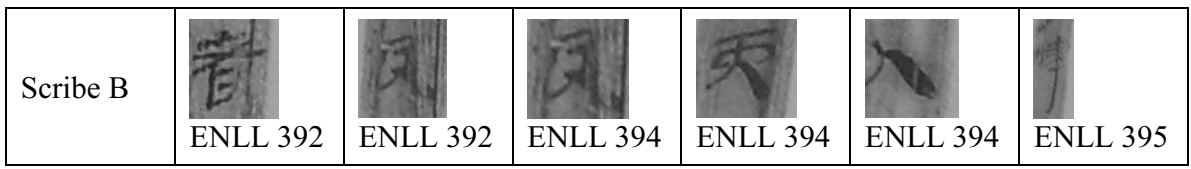

Although three scribes took part in writing the ENLL manuscript, scribe A was the main one, as he was responsible for writing more than half of the text; while scribes B and C were assistant scribes. Scribe A being the main scribe was due to the fact that he was skilled in writing and mastered polished writing methods. Compared to the handwriting of the other manuscripts found in the Zhangjiashan tomb no. 247, it is probably that these three scribes only wrote the ENLL manuscript.

As we know that all the scribes used the same text layout to write the manuscript, it seems that either they had all agreed to use the same one before writing; or someone responsible for writing the manuscript, probably scribe A, had informed and guided them to finish in this way. The scribes took turns to write slips of a category of statutes or even a single strip, which suggests that they must have participated in writing this manuscript at the same place.

There must be a reason that the ENLL manuscript was produced in this way, as one scribe was responsible for writing most of the strips, while the others for writing the rest. I assume that this particular process of production may have enabled the scribes to write the ENLL text more quickly and flexibly: they could take turns to write the manuscript when the main scribe A was not available; or when one scribe, especially scribe A, wrote the slips, the other two assistant scribes assisted him in preparing stationery or slips for writing. The fact that the manuscript was bound after writing is also in agreement with this mode of production. ${ }^{10}$

The reason that three scribes wrote together for the ENLL manuscript is likely due to a short amount of time. This point is further supported by the large number of writing mistakes found in the ENLL manuscript, which strongly proves that they did not do proofreading after writing. ${ }^{11}$

The author has argued that the ENLL manuscript was written in the second year of Empress Lü (186 BCE), which is around the death of the tomb

${ }^{10}$ Li Jingrong discusses the binding of the ENLL manuscript, see Li Jingrong 2014: 23 27.

${ }^{11}$ See You Yifei 2013: 42-44; Li Jingrong 2014: 83-88. 
owner. It is most likely that the manuscript had never been used by the owner and produced for his funeral. ${ }^{12}$ The manuscript was probably required urgently for the funeral, which might push the scribes to write the manuscript fast.

Studying the physical features of a manuscript, especially its writing and the scribal hands, can better understand the way of its production. The writing method provides insights into the nature and purpose of a manuscript.

\section{References}

CHEN Yaojun 陳耀鈞, and Yan Pin 閻頻 1985: “Jiangling Zhangjiashan Han mu de niandai ji xiangguan wenti” 江陵張家山漢墓的年代及相關問題. Kaogu 1985 (12), 1124-1129.

GIELE, Enno 2005: "Signatures of 'Scribes' in Early Imperial China." Asiatische Studien 59, no. 1: 353-87.

HULSEWÉ, A. F. P 1985: Remnants of Ch'in Law: An Annotated Translation of the Ch'in Legal and Administrative Rules of the 3rd Century B.C., Discovered in Yun-meng Prefecture, Hu-pei Province, in 1975. Sinica Leidensia, Vol. 17. Leiden: E.J. Brill.

LI Jingrong 2014: The Ernian lü ling Manuscript, Staats- und Universitätsbibliothek E-Dissertationen, http://ediss.sub.uni-hamburg.de/volltexte/2014/6923, published in August 2014.

Jingzhou diqu bowuguan 荊州地區博物館 1985: “Jiangling Zhangjiashan sanzuo Hanmu chutu dapi zhujian” 江陵張家山三座漢墓出土大批竹簡. Wenwu (1): 1-8.

PENG Hao 彭浩, Chen Wei 陳偉, and Kudô Motoo 工藤元男 eds. 2007: Ernian lü ling yu Zouyanshu (Zhangjiashan ersiqi hao Hanmu chutu falü wenxian shidu) 二年律令與奏 獻書(張家山二四七號漢墓出土法律文獻釋讀). Shanghai: Shanghai guji, 2007.

TOMIYA Itaru 冨谷至 2010: “Jiangling Zhangjiashan ersiqi hao Han mu chutu zhujiantebie shi guanyu Ernian lü ling” 江陵張家山二四七號漢墓出土竹簡 — 特別是 關於《二年律令》. In Jianbo yanjiu erlinglingba 簡帛研究二零零八, edited by Bu Xianqun and Yang Zhenhong. Guilin: Guangxi shifa.

XU Shen 许慎 1963: Shuo wen jie zi 说文解字. Beijing: Zhonghua.

YATES, Robin D. S 2014: "The Changing Status of Slaves in the Qin-Han Transition." In Birth of an Empire: The State of Qin Revisited, edited by Yuri Pine, Gideon Shelach, Lothar von Falkenhausen, and Robin D.S. Yates, 206-223.

YOU Yifei 遊逸飛 2013: "Shi lun Zhangjiashan Han jian Er nian lü ling de jichu ewu" 試論張家山漢簡《二年律令》的幾處訛誤. In Luo jia shi yuan (10): 41-50.

Zhangjiashan ersiqi hao Han mu zhujian zhengli xiaozu 張家山二四七號漢墓竹簡整理小組 2001: Zhangjiashan Han mu zhujian (ersiqi hao mu) 張家山漢墓竹簡(二四七號墓). Beijing: Wenwu.

ZHANG Zhongwei 張忠煒 2012: Qin Han lü ling faxi yanjiu chubian 秦漢律令法系研 究初編. Beijing: Shuihui kexue wenxian.

\footnotetext{
${ }^{12}$ Li Jingrong 2014: 82.
} 